The Pakistan Development Review

38 : 4 Part II (Winter 1999) pp. 757-768

\title{
The Theory and Practice of Agricultural Income Tax in Pakistan and a Viable Solution
}

\author{
M. GHAFFAR CHAUDHRY
}

\section{INTRODUCTION}

Pakistan has a history of taxing agriculture through the land revenue system. Being income and price inelastic, the replacement of the system with agricultural income tax is considered inevitable for meeting the financial needs of a growing national economy. In fact, under pressures from World Bank and International Monetary Fund (IMF), Pakistan introduced various variants of agricultural income tax in the past and in full during 1993 and 1996 respectively [World Bank (1999)]. However the introduction of agricultural income tax is a highly controversial issue in Pakistan, in government circles as well as among professional researchers and economists. Out of the nine commissions [Pakistan (1959, 1960, 1963, 1964, 1970, 1975, 1986, 1988, 1989 and 1993a)] that studied agricultural taxation only two recommended it. [Pakistan (1960, 1993a)]. The remaining seven favoured the existing land revenue system. The studies of individual economists are no less controversial in this respect. There seems to be a general consensus among such writers as [Hamid (1970); Yaqub (1971); Chowdhury (1971); Khan (1991) and World Bank (1999)] on the repeal of land revenue system in favour of agricultural income or graduated land tax. Against this an equal number of economists, have shown dissatisfaction with agricultural income tax as an effective tool of taxing agriculture [Ahmad and Stern (1989); Bird (1974); Bird and Oldman (1990); Chaudhry and Maan (1993); Gold and Foster (1972) and Newbery (1987)].

While the merits and demerits of agricultural income tax perceived by various writers in theory and practice are a major source of the controversy, the present paper attempts to provide an assessment of introducing the policy in Pakistan in the light of typical characteristics of a good tax policy if only to recommend viable alternatives.

M. Ghaffar Chaudhry is Joint Director at the Pakistan Institute of Development Economics, Islamabad.

Author's Note: Author bears full responsibility for the ideas expressed in this paper. 
In line with these objectives, the paper's outline consists of five sections. Following the current introductory section, the benefits of agricultural income tax in terms of revenue generation, resource-use efficiency and as a fair and just system of taxation are spelled out in Section 2. Some of its limitations as an effective policy tool under Pakistan's conditions are discussed in Section 3. In Section 4, policy recommendations are made. The final Section 5 contains concluding remarks.

\section{MERITS OF AGRICULTURAL INCOME TAX}

The theoretical desirability of agricultural income tax follows from a number of considerations.

The case for agricultural income tax follows from low contributions of agriculture to government's tax revenue. It is argued that, although agriculture's share in national income exceeds 23 percent, revenue raised from the sector is, at best, minuscule [World Bank (1999)]. With limited tax potential of many subsistence farmers, the land revenue system needs to be replaced by agricultural income tax for any significant increase in revenues from this sector. It is further argued that since the discrimination against agriculture in the form of low prices has ended or diminished in recent years, there exists a large untaxed potential which can be tapped by taxing this sector [Khan (1991) and World Bank (1999)].

The justification for agricultural income tax is further built on criticism of land revenue system as an outmoded, regressive and price and income inelastic system of taxation. By contrast the progressive rate structure of agricultural income tax permits heavier taxation of those with sufficient ability to pay and exemptions for the poor. Thus the system of agricultural income tax is helpful in achieving the most cherished goals of economic development such as equitable income distribution, poverty alleviation and resultant better nutrition in the rural areas. It has also been argued that the income-based tax system would be income and price elastic and would rid the economy of costly and politically sensitive periodic land assessments for increases in government's tax revenue from agriculture [Chowdhury (1971); Hamid (1970); Khan (1991) and World Bank (1999)].

The large and prosperous farmers are typically characterised by underutilisation and inefficient use of land resources. The cultivation intensity of land varies inversely with farm size and equals 150 percent on farms under 5.0 acres but is only 70 percent for farms exceeding 150 acres [Pakistan (1993)]. Therefore rising and higher tax rates under income tax should force many large farms to use their land more intensively and efficiently.

The desirability of agricultural income tax also follows from the benefit approach as large farmers have been argued to benefit more from government's policies of input subsidies, institutional credit and extension and research services. 
The introduction of agricultural income tax may prove to be cost effective as tax assessment and collection may be undertaken by income tax department and the services of provincial revenue departments may no longer be needed after repeal of land revenue system.

Finally, the higher tax rates for the well-to-do may restrict mass consumption by the rich and the policy may ensure stability of prices of most of the consumer goods.

\section{THE LIMITATIONS OF AGRICULTURAL INCOME TAX}

In spite of its theoretical appeal, the imposition of agricultural income tax in Pakistan seems neither to be practicable nor justified on any grounds whether economic, social or political. This can be seen from the following discussion.

The rhetoric on agricultural income tax is premised on weak foundation and there is no reality in such statements that hold that agriculture pays no tax or that it is under-taxed despite the existence of considerable tax potential especially after the implementation of the structural adjustment programme raising agricultural commodity prices to world levels and ensuring end of implicit taxes in agriculture. The fact of the matter is that agriculture in Pakistan is subjected to all kinds of direct, indirect and implicit taxes and the practice continues unabated. It is true the contribution of direct taxes in agriculture is miniscule, but it is also a fact that it is over-burdened with indirect and implicit taxes. And that could be the underlying reason of low share of direct taxes. ${ }^{1}$

Taking the tax system as a whole, incidence studies have shown that agriculture accounts for the payment of 35-46 percent of total tax revenue in Pakistan [Qureshi (1986)]. As agriculture generates only 23 percent of national income, the tax burden in agriculture would, at least, be double that of the nonagricultural sector. But since agriculture supports nearly 70 percent of Pakistan's population, agriculture's real tax burden in terms of per capita incomes should be more than six-times the tax burden in the non-agricultural sector.

Over and above what, agriculture pays by way of indirect taxes, it is also subjected to implicit taxes in the form of low agricultural commodity prices. Basing our calculations on comparisons of parity and support prices, Table 1 reports on the probable magnitude of implicit taxes from 1995-96 to 1997-98.

It is clear from Table 1 that support prices of agricultural commodities (with the exception of IRRI rice during 1997-98) were at best significantly lower than their corresponding parity prices. As a consequence, implicit taxation of agriculture was

${ }^{1}$ In view of the overwhelming emphasis on indirect and implicit taxes in agriculture, the low magnitude of direct taxes should not drastically change its burdens relative to those in the non-agricultural sector. 
Table 1

Implicit Tax in Pakistan's Agriculture from 1995-96 to 1997-98

\begin{tabular}{|c|c|c|c|c|}
\hline \multirow[b]{2}{*}{$\begin{array}{l}\text { Years and } \\
\text { Commodities }\end{array}$} & \multicolumn{2}{|c|}{ Commodity Prices (Rs Per Tonne) } & \multirow[b]{2}{*}{$\begin{array}{l}\text { Marketed Output } \\
\text { (000 Tonnes) } \\
\text { (3) }\end{array}$} & \multirow[b]{2}{*}{$\begin{array}{l}\text { Total Implicit } \\
\text { Tax (Rs Million) } \\
\quad=(1-2) \mathrm{X}(3)\end{array}$} \\
\hline & $\begin{array}{c}\text { Farm Gate Parity } \\
\text { Price } \\
(1)\end{array}$ & $\begin{array}{l}\text { Support } \\
\text { Price } \\
(2)\end{array}$ & & \\
\hline \multicolumn{5}{|l|}{ 1995-96 } \\
\hline Wheat & 9850 & 4325 & 3740 & 20664 \\
\hline Sugarcane & 1050 & 538 & 45230 & 23158 \\
\hline Basmati Rice & 7775 & 5550 & 955 & 2125 \\
\hline IRRI Rice & 3525 & 2800 & 1179 & 855 \\
\hline Seed Cotton & 19600 & 10000 & 5406 & 51898 \\
\hline Total & - & - & - & 98700 \\
\hline \multicolumn{5}{|l|}{ 1996-97 } \\
\hline Wheat & 9490 & 6000 & 3448 & 11344 \\
\hline Sugarcane & 1146 & 600 & 41998 & 22931 \\
\hline Basmati Rice & 7252 & 6382 & 610 & 531 \\
\hline IRRI Rice & 3646 & 3220 & 1747 & 774 \\
\hline Seed Cotton & 23570 & 12500 & 4782 & 53893 \\
\hline Total & - & - & - & 89473 \\
\hline \multicolumn{5}{|l|}{$1997-98$} \\
\hline Wheat & 9774 & 6000 & 3984 & 15036 \\
\hline Sugarcane & 1089 & 875 & 53104 & 11364 \\
\hline Basmati Rice & 8768 & 7750 & 736 & 749 \\
\hline IRRI Rice & 3667 & 3825 & 2052 & -324 \\
\hline Seed Cotton & 21955 & 14375 & 4689 & 35543 \\
\hline Total & - & - & - & 62368 \\
\hline
\end{tabular}

Source: [APCom (1997, 1998) and Pakistan (1999)].

Note: Parity prices are import parity prices in the case of wheat and sugarcane and export parity prices in the case of rice and cotton. Farm-gate parity prices were calculated by adding and subtracting transport costs from farm to market respectively from import and export parity prices given in the source. Marketed output equals total output of seed cotton and sugarcane and procured and exported amounts respectively of wheat and rice.

nearly Rs 99 billion, Rs 90 billion and Rs 63 billion respectively for 1995-96, 1996-97 and 1997-98. Although the implicit taxes seem to have fallen over this 3 years period, most of the decline was the result of falling cotton and sugarcane prices in the international market. The implication of this finding is that implicit taxes could rise again to 1995-96 levels or beyond with reversal of price trend in the international market.

The above information indicates non-existence of any tax potential in agriculture. It is further vitiated by falling profit rates of agriculture in recent years. This situation results from, (1), widespread crop failures and (2),sharper increases of 
prices of key agricultural inputs relative to those of major agricultural commodities [Chaudhry (1995) and APCom (1997, 1998)] under mounting World Bank/IMF pressures for complete removal of subsidies to farm sector.

The claim that imposition of agricultural income tax would be commensurate with automatic additions to tax revenues because of its high income and price elasticities, is equally untenable. In fact, there is substantial evidence to the contrary. It has long been established that a presumptive income tax whether based on PIUs per acre or rental value of land would really amount to no more than a land tax in disguise [Bird (1974)]. As land taxes are inherently income and price inelastic, presumptive income tax should be similarly classified. According to Wald (1959) "the inelasticity which characterises most land taxes is organic, that is to say, it comes from within the tax as a result of stable tax rate to a tax base that is not kept current". Also unlike the stable tax yield of a proportional land tax from year to year, the progressive rate structure of agricultural income tax that varies directly with farm size or PIUs of an agricultural holding can be blamed for declining (in absolute terms) government revenues over time because of the operation of inheritance laws and other factors. As this is contrary to the very basic tenet of a good tax policy; introduction of agricultural income tax can only be a futile and self-defeating exercise.

The operation of inheritance laws would continue to cause division of agricultural holdings to smaller size farms and consequent progressive reduction in government revenue. Between 1970 and 1990 the average farm size has already fallen from 13.0 to 9.4 acres [Pakistan $(1975,1993)$ ] and is likely to fall further in the coming years. As the recommended agricultural income tax policy also provides for tax exemptions below a certain farm size, it may encourage tax evasions through registration of land ownership in the name of relatives [Newbery (1987)] or even through Benami transfers in collusion with revenue officers as under land reforms [Herring and Chaudhry (1974)]. While the fall in government revenues is imminent, its magnitude would most likely vary directly with steepness of progression, rate of subdivision of agricultural holdings, and the tax exemption limit and inversely with economies of scale in agriculture. It may also be noted that the agricultural income tax would result in narrowing the tax base as against the principle of broadly-based tax of a good tax system because the narrower the tax base, the higher the tax rate will have to be to generate a given amount of revenue [World Bank (1988)].

To the extent that agricultural income tax adds to the temptation of evasion, the equity argument is considerably dissipated. The provincial revenue departments in some cases have resorted to use crop land as a base for agricultural income tax which violates both equity and efficiency principles by progressively alleviating tax burdens of larger farms with falling cultivation intensity as earlier discussed.

In comparison to the flat rate land taxes that are easy to manage, the progressive rate structure of agricultural income tax makes the system increasingly 
complex and would be difficult to enforce administratively. A graduated land tax policy for effective implementation would require efficient and honest administration because the incentive to evade taxes increases with the introduction of progressive tax rates [Bird and Oldman (1990)]. Under the present situation of poor administration, rampant corruption and favouritism, the successful implementation of a graduated land tax, like the various land reform attempts, can be seriously doubted. Surrey is emphatic on this: "the income tax may well be favourite of the twentieth century but it demands twentieth century administration. There are many who urge these variants without any comprehension of the complex legal and accounting problems which they create" [Surrey (1975)]. Thus the landbased agricultural income tax policy can hardly be recommended for implementation even on administrative grounds.

\section{REFORMING THE AGRICULTURAL TAX SYSTEM}

Although equitable taxation of agriculture is a desirable objective, direct progression in the form of either the extension of general income tax or an introduction of a graduated land tax, as shown in the foregoing, suffers from formidable practical problems of implementation and is unsuited to conditions in Pakistan's agriculture. This being so, progression in agricultural taxation can be introduced only indirectly by appropriately combining the proportional land tax and a tax on marketed output. ${ }^{2}$ This two-tier system of agricultural taxation has all the desirable characteristics of a rational tax policy. For example, a proportional land tax based on owner's farm area - cultivated or uncultivated - is preferable over the graduated land tax because, as was argued before, it will keep the tax base stable and relatively broader, will reduce the temptation for undue subdivision of holdings, will avoid the possibility of declining absolute tax revenues over time, will ensure efficient use of resources, and above all will be easy to administer.

A proportional land tax, however is inherently handicapped by its inequitableness, and income and price inelasticities. A tax on the marketed produce is best suited to overcome these deficiencies of agricultural taxation. In the words of Wald, "In certain respects a tax on marketed produce has unique qualifications as an instrument of equitable taxation ........ Moreover, the tax is responsive to changes in production and prices ..... The incidence of such a tax, as distinguished from that of land revenue, will be appropriately heavy on the large land holders. While the small land holder, to the extent his crop is consumed and not sold by him will not have to bear the tax at all" [Wald (1959)]. In Pakistan the appropriateness of this so-called indirect progression, is greatly enhanced as the tenants will not be subjected to

${ }^{2}$ The progression is essentially indirect, since the proportional rate on marketed surplus is converted into a progressive rate per acre because of relatively higher marketed surplus of the large farmers. 
heavier tax rates along with the large land holders-the largest producers of marketed surplus. The tax base will be widening and the revenue from the tax on marketed produce will be expected to grow at the rate of growth of the marketed surplus plus the rate of increase in prices of agricultural commodities. In case of crop failures and market gluts, tax payments by farmers will automatically be reduced for relief against natural calamities. The tax may be implemented through the local bodies administration to avoid any additional cost as the local bodies in the recent past were collecting a similar tax on agricultural commodities. The tax in addition will avoid tax evasion as the farmers will be easily approachable at the market place. Moreover, there will be less corruption because the tax collectors will be closely supervised.

To a certain extent a tax on marketed produce may be accompanied by deleterious effects on farm and marketed outputs. This can be expected because no system of taxation can be perfectly neutral with respect to allocation [World Bank (1988)]. It may, however, be noted that the disincentive effect of the policy on output and marketed surplus can be considerably reduced by the presence of a heavy land tax, especially on unused lands.

It is difficult, if not impossible, to suggest any precise rate structure of the two taxes for want of appropriate statistics. It would, to a large degree, depend on revenue demand of the government from the sector. However, the system could be considerably simplified if half the revenue demand from agriculture is met through a land tax and the other half through a tax on marketed output. As agriculture is already over taxed in the form of indirect and implicit taxes, it is an absolute necessity to discontinue indiscriminate use of fiscal and price policies for massive transfer of resources from agriculture to non-agricultural sector. This, in precise terms, could only be done by ensuring effective transmittal of world prices to agriculture in Pakistan through establishment of regulated private marketing system with close supervision by the government to guard against malfunctioning. In view of the volatile nature of world prices, fixation of domestic agricultural commodity prices may be undertaken on the basis of five-year moving average of world prices. The price policy thus evolved would have built-in stability of prices and consistency with zero support to agriculture as taxes in years of high world prices would be automatically canceled out by positive transfers into agriculture during years of low world prices.

\section{CONCLUDING REMARKS}

As discussed in the foregoing, agriculture is subjected to direct, indirect and implicit taxes. Its contribution therefore to total tax revenues must be based on the incidence analysis of all three which would reveal the huge and oppressive burden of taxes on agriculture.

While increasing dependence on direct taxes would be highly desirable, progression in agricultural taxation cannot be introduced by the introduction of a general income tax or a graduated land tax due to many practical problems of a 
fundamental nature. If equitable taxation of agriculture is at all desirable, progression in land taxes has to be achieved in an indirect way. For this purpose, a two-tier system of agricultural taxation, involving a proportional land tax on the pattern of land revenue and a uniform tax on marketed surplus can be recommended. Devised in a proper manner, the two-tier system would be equitable, responsive to changes in income and inflation and easy to implement, manage and operate even with the present administrative set-up. A uniform rate structure of a tax on marketed output may prove to be progressive in its impact, if the tax is ultimately paid by the farm sector and if the

marketed surplus varies directly with farm size. There can be little doubt that the two relationships would largely hold as far as Pakistan's agriculture is concerned.

\section{REFERENCES}

Ahmad, Ehtisham, and Nicholas Stern (1989) Taxation for Developing Countries. In Hollis B. Chenery, and T. N. Srinivasan (eds) Handbook of Development Economics. Amsterdam: North-Holland.

APCom (1997) Support Price Policy for Wheat, Rice, Cotton and Sugarcane. Islamabad. (APCom Series Nos. 158, 159, 160 and 163.)

APCom (1998) Support Price Policy for Wheat, Rice, Cotton and Sugarcane. Islamabad. (APCom Series Nos. 167, 168, 169 and 174.)

Bird, Richard, M. (1974) Taxing Agricultural Land in Developing Countries. Cambridge: Massachusetts.

Bird, Richard, M., and Oliver Oldman (1990) Taxation in Developing Countries. Baltimore: Johns Hopkins University Press.

Chaudhry, M. Ghaffar, and A. H. Maan (1993) Taxation of Agriculture in Pakistan: Structure, Magnitude and Economic Implications. In Agha Sajjad Haider et al. (eds) Agricultural Strategies in the 1990s Issues and Policies. Islamabad: Pakistan Association of Agricultural Social Scientists.

Chaudhry, M. Ghaffar, and A. H. Maan (1995) Recent Input-Output Price Policy in Pakistan's Agriculture: Effects on Producers and Consumers. The Pakistan Development Review 34: 1

Chowdhury, A. H. M. N. (1971) A Proposal for Agricultural Tax Reform. Pakistan Economist Incorporating Finance and Industry 10.

Gold, Harold, and Edward Foster (1972) Measuring Equity in the Taxation of Agricultural Land: A Case Study of Nepal. Land Economics 48: 3.

Hamid, J. (1970) Suggested Approach to Agricultural Taxation Policy in West Pakistan. The Pakistan Development Review 10: 4.

Herring, Ronald, and M. Ghaffar Chaudhry (1974) The 1972 Land Reforms in Pakistan and their Economic Implications: A Preliminary Analysis. The Pakistan Development Review 13:3 .

Khan, Mahmood Hasan (1991) Resource Mobilisation from Agriculture in Pakistan. 
The Pakistan Development Review 30: 4.

Newbery, David (1987) Agricultural Taxation: The Main Issues. In David Newbery and Nicholas Stern (eds) The Theory of Taxation for Developing Countries. New York: Oxford University Press.

Pakistan, Government of (1959) Report of the Food and Agriculture Commission. Karachi.

Pakistan, Government of (1960) Taxation Enquiry Committee Report. Karachi.

Pakistan, Government of (1963) Report of Fact-Finding Committee on Agricultural Taxation. Karachi.

Pakistan, Government of (1964) Report of the Commission on Taxation and Tariff. Rawalpindi.

Pakistan, Government of (1970) Report of the Study Group on Agricultural Policy. Rawalpindi.

Pakistan, Government of (1975) Pakistan Census of Agriculture: All Pakistan Report. Vol. 1, Lahore.

Pakistan, Government of (1986) Report of the National Taxation Reform Commission. Islamabad.

Pakistan, Government of (1988) Report of the National Commission on Agriculture. Islamabad.

Pakistan, Government of (1989) Report of the Committee of Experts on Taxation of Agricultural Incomes. Islamabad.

Pakistan, Government of (1993) 1990 Census of Agriculture: All Pakistan Report. Vol. 1. Lahore.

Pakistan, Government of (1993a) Report of Prime Minister's Task Force on Agriculture. Islamabad: Ministry of Finance, Revenue and Economic Affairs.

Pakistan, Government of (1999) Economic Survey 1998-99. Islamabad: Finance Division.

Qureshi, M. L. (1986) Incidence of Taxation in Pakistan. A Report prepared for the National Taxation Reforms Commission. Lahore.

Surrey, S. S. (1975) The Administration in Underdeveloped Countries. In Richard M. Bird and Oliver Oldman (eds) Readings on Taxation in Developing Countries. Baltimore: The Johns Hopkins Press.

Wald, M. P. (1959) Taxation of Agricultural Land in Underdeveloped Economies. Cambridge, Massachusetts: Harvard University Press.

World Bank (1988) World Development Report 1988. Washington, D. C.: The World Bank.

World Bank (1999) Agricultural Taxation in Pakistan. Washington, D. C.: The World Bank. (Report No. 18935-Pak.)

Yaqub, M. (1971) Need and Scope for Additional Taxation with Special Reference to Agricultural Taxation. Pakistan Economist Incorporating Finance and Industry 10. 


\section{Comments}

Tax on agricultural incomes has been the subject of substantial controversy in the Indo-Pakistan sub-continent. During the Mughal period, landlords as agents of kings collected land revenue as land rent on the basis of per acre production [Habib (1982), 235-240]. During the British period the fixed land rent was the major source of government revenue [Kumar and Desai (1982), p. 928]. This source of revenue fell with the weakening of British power in the sub-continent from 53 percent of total taxes in 1900-01 to 7 percent in 1946-47. The revenue collected during the Mughal and the British administrations was not a tax on agricultural incomes as conventionally understood, but a graduated surcharge on land revenue with a high exemption limit and low rates [Qureshi (1987), p. 159].

We can assess Mr Ghaffar's paper from five angles: (a) desirability; (b) revenue productivity; (c) taxpayers compliance; (d) tax administration; and (e) equity, social justice, fairness, income distribution. We will discuss these briefly.

In the last fifty years a number of expert committees and studies have examined the possibility of introducing a direct tax on farm incomes. These studies have covered almost the whole field of agricultural taxation, including the feasibility of extending the general income tax law to agricultural incomes. Most of the studies undertaken during the 1960s and the 1970s maintained that the agriculture sector was already under heavy implicit and explicit taxes through hidden transfers, and therefore it was not capable of bearing the burden of additional taxation [Hornby (1968), p. 105; Dixit (1971), p. 385; Azher (1973), p. 83; Newbery (1974), p. 38; Newbery (1987), pp. 367-370; Qureshi (1987), p. 159; NCA (1988), p. 529]. These studies concluded that extending income tax laws to agricultural income would not be a productive source of additional revenue for the government [Joshi et al. (1968), p. 329; Ahmad and Stern (1991), p. 253] and if a tax was imposed its yield would be negligible and its effect would be harmful to the sector's productive capacity [LUMS (1986), p. 63; NCA (1988), p. 536].

Studies undertaken in the 1980s pointed out that although the vast majority of people engaged in agriculture were living below the subsistence level, a number of them enjoyed large incomes. Since their income is exempt from tax these landlords live luxurious lives and have made substantial investments in city real estate, creating a situation of antagonism among the trading and industrial classes as well as the professional class who are forced to pay income tax. This antagonism has discouraged tax compliance and provided strong incentives for tax evasion among business and professional income tax payers [Hamid (1970), p. 438; NTRC (1986), p. 134; NCA (1988), p. 530; Coopers and Lybrand (1989), pp. 3-8].

Assessment of the agricultural tax potential by the government, researchers and international financial institutions varies considerably from Rs 2.0 billion to Rs 60 billion. This assessment is based on various methods, such as extension of existing income tax 
laws [NTRC (1986), p. 160; Mohammad (1987), pp. 424-425] or land tax levied on potential yields with a simple rate structure [Qureshi (1987), p. 12; NCA (1988), p. 537; Ahmad and Stern (1991), pp. 255-259], PIU's, presumptive tax on agriculture. Some research studies argued that the revenues from agricultural income tax would be so low that it would not meet even the cost of tax collection. It is also argued that it would be very difficult to administer the tax because farmers do not keep accounts.

These no-arguments confuse the basic issue. At the conceptual level, it needs to be underscored that the individuals and not the sectors pay income taxes. Therefore, an individual earning incomes above a certain level is obliged to pay income taxes irrespective of the fact whether a person earns income from agriculture, manufacturing or any other activity. There is no rationale for treating incomes earned from different sources differently for income tax purposes. Since the distribution of land is highly skewed, agricultural incomes are also distributed very unevenly, and the imposition of income tax on agriculture would lead to a fairer distribution of incomes and wealth in rural Pakistan. At a conceptual level, therefore there is hardly any room for disagreement over the desirability of imposing agricultural income tax.

One may not dispute that because of government design domestic prices of most of the agricultural goods have all along remained below world market prices by a wide margin. It has been rightly pointed out in the paper that depressed prices amount to an implicit taxation of agricultural commodities. This has caused resource transfer from the agriculture sector resulting in lower incomes of the farmers than the income they would have earned if the international market prices of the output had prevailed. Yet it is no argument for retaining the present system of tax exemptions to agricultural incomes because implicit taxation affects the rich and the poor equally, while the highest impact of a progressive tax on agricultural income, imposed properly, would be on rich farmers. The majority of the small farmers will be exempt from the tax. The equity and fairness considerations demand the imposition of income tax on all the groups irrespective of the yield and cost.

The argument that a tax on agricultural income would pose considerable problem of compliance and administrative inconvenience to tax agencies should not be taken as an excuse. A handful of studies suggest that initially big landowners be brought into the tax net and once the system is in place, the tax net can be enlarged.

The proposed structure of two taxes - a land tax and a tax on marketed output — was discussed in detail in the past [Task Force Report (1996)]. The system, however, was not supported because of complications.

One must be careful in arguing the influence of external agencies on the imposition of agricultural income tax. A number of Tax Reform Committees/ Commissions have supported the proposal of a tax on agricultural incomes. Since the early 1980s the ongoing structural adjustment programmes and the economic and political developments in the country have given rise to a renewed interest in favour of imposition of tax on agricultural incomes. 


\section{REFERENCES}

Ahmad, E., and N. Stern (1991) The Theory and Practice of Tax Reform in Developing Countries. Cambridge: Cambridge University Press.

Azher, B. A. (1973) Agricultural Taxation in West Pakistan. The Pakistan Economic and Social Review Autumn: 76-84.

Coopers, and Lybrand (1989) Study of Direct Taxation. Final Report to the Government of Pakistan, December, Coopers and Lybrand, London.

Dixit, A. (1971) Short-run Equilibrium and Shadow Prices in a Dual Economy. Oxford Economic Papers 23:3 384-400.

Habib, I. (1982) Agrarian Relations and Land Revenue. In T. Raychaudhuri and I. Habib (eds) The Cambridge Economic History of India, Volume 1 (1200-1750). Cambridge: Cambridge University Press.

Hamid, J. (1970) Suggested Approach to Agricultural Taxation Policy in West Pakistan. The Pakistan Development Review 10:4 422-447.

Hornby, J. M. (1968) Investment and Trade Policy in the Dual Economy. Economic Journal 78:3 96-107.

Joshi, T. M., N. Anjanniah, and S. V. Bhende (1968) Studies in the Taxation of Agricultural Land and Income in India. New Delhi: Asia Publishing House.

Kumar, D. (1982) The Fiscal System. In D. Kumar and M. Desai (eds) The Cambridge Economic History of India, Volume 2 (1757-1970). Cambridge: Cambridge University Press.

Kumar, D., and M. Desai (eds) (1982) The Cambridge Economic History of India, Volume 2 (1757-1970). Cambridge: Cambridge University Press.

LUMS (1986) Agricultural Taxation Issues in Pakistan. Lahore: Lahore University of Management Sciences.

Mohammad, F. (1988) Agricultural Taxation in Pakistan Revisited. The Pakistan Development Review 27:4 577-594.

NCA (1988) Final Report of the Commission. Government of Pakistan, Islamabad.

NTRC (1986) National Tax Reform Commission Report. Ministry of Finance, Government of Pakistan, Islamabad.

Newbery, D. (1974) The Robustness of General Equilibrium Analysis in the Duel Economy. Oxford Economic Papers 26:1 32-41.

Newbery, D. (1987) Taxation and Development. In Newbery and N. Stern (eds) The Theory of Taxation for Developing Countries. New York: Oxford University Press.

Newbery D., and N. Stern (eds) (1987) The Theory of Taxation for Developing Countries. A World Bank Research Publication. New York: Oxford University Press. Task Force (1996) Report of the Task Force on Fiscal Reforms. Islamabad. November.

Planning Commission,

Muhammad Aslam Khan

Islamabad. 